\title{
PROBLEMATIKA TMELENÍ CEMENTOVÝCH PODKLADŮ VYSTAVENÝM ÚČINKŮM ZMĚNY TEPLOTY
}

\section{PROBLEMATICS OF SEALING CEMENT SUBSTRATES EXPOSED TO THE EFFECTS OF CHANGIGNG TEMPERATURES}

\author{
Ing. Adam Boháček ${ }^{\text {*; }}$ Ing. Michal Brandtner \\ ${ }^{1}$ Vysoké učení technické v Brně, Fakulta stavební, Veveři 331/95, 60200 Brno, Česká republika \\ *korespondenční autor: bohacek.a@fce.vutbr.cz
}

\begin{abstract}
ABSTRAKT CZ
Tento článek se zabývá problematikou řešení tmelení spojů materiálů, u kterých může docházet $\mathrm{k}$ porušení tmelené spáry vlivem teplotních změn. Jako základní podkladní materiál je $\mathrm{v}$ tomto př́ípadě vybrán sklocement. Spolu s vybranými tmely z něj jsou vyrobeny zkušební vzorky, které jsou testovány podle platné evropské normy ČSN EN ISO 9047 Stavební konstrukce - Těsnící hmoty - Stanovení přilnavosti a soudržnosti tmelů při proměnlivé teplotě. Výsledky tohoto testování jsou hodnoceny vizuální kontrolou a přeměřením případných porušení posuvných měřítkem. Na základě vyhodnocení daných výsledků testování není možné ani jeden z testovaných tmelů doporučit ke tmelení sklocementových podkladních materiálů.
\end{abstract}

Klíčová slova: Tmel, tmelený spoj, zkušební těleso, přilnavost, soudržnost

\section{ABSTRACT}

This article deals with the solution of sealing joints of materials in which the sealed joint may be damaged due to temperature changes. In this case, glass cement is selected as the base material. Together with selected sealants, test specimens are made from it, which are tested according to the valid European standard ČSN EN ISO 9047 Building construction - Sealants - Determination of adhesion and cohesion of sealants at variable temperatures. The results of this testing are evaluated by visual inspection and remeasurement of any violations of the sliding scale. Based on the evaluation of the given test results, it is not possible to recommend any of the tested sealants for sealing glass-cement base materials.

Key words: Sealant, sealed joint, test specimen, adhesion, cohesion

\section{1 ÚVOD}

Problém, jak ve stavebnictví spojit jednotlivé materiály, provází lidstvo prakticky od jeho civilizovaných počátků, a i dnes naše společnost potká tmelené spoje takřka na každém kroku. Do začátku 20. století byly však veškeré materiály používané pro tmelení pouze př́rodního charakteru. Postupem času se ale díky rozvoji technologií a chemického průmyslu přesunuly materiály používané pro tmelení do oblasti složitých chemických sloučenin. I díky tomuto vývoji došlo v posledních dvou desetiletích $\mathrm{k}$ obrovskému pokroku v technologii a aplikaci stavebních tmelů. [1]

Hlavním účelem tmelu je zabránit vzduchu, vodě a dalším látkám před vstupem do konstrukce nebo před jejím opuštěním a umožnění určitého rozsahu pohybu podkladů. Tmely zabudované do spár budov 
dále zajišt’ují tepelnou a zvukovou izolaci a často přispívají k požární odolnosti konstrukce. [2] Spoje a otvory mezi konstrukčními prvky lze nalézt v mnoha různých částech budov nebo stavebních konstrukcí, např́klad mezi prefabrikovanými betonovými prvky ve fasádách, kolem oken a dveří, ve spojení mezi podlahami a stěnami atd. Ačkoli se spoje nachází v mnoha oblastech stavby je zjevné, že mezi nimi panují značné rozdíly. [2,3] Nejen z těchto důvodů musí být tmelené spoje vždy navrženy tak, aby odolaly všem vnitřním i vnějším vlivưm, mezi ty, jež tmelené spoje nejvíce zatěžují pak patří vlivy klimatické. [3]

Pakliže předpokládáme, že tmelený spoj bude těmto vlivưm vystaven je vhodné vybírat tmel, který je proti těmto podmínkám rezistentní. Ale vzhledem $\mathrm{k}$ nepřebernému množství výrobků na českém trhu a k tomu, že ne vždy doporučení výrobce odpovídá skutečné odolnosti tmelu proti těmto vlivům, vybrat takový tmel není vůbec nic snadného. Cílem této práce je proto porovnání kvality tmelů právě po vystavení klimatickým vlivům a jejich pozdější soudržnosti s podkladním materiálem, a to pomocí vhodných, normou schválených zkušebních postupů.

\section{MATERIÁL}

Pro účely tohoto výzkumu je zvolen jako podkladní materiál sklocement, který při tmelení vykazuje jistou problémovost, která spočívá $\mathrm{v}$ prítomnosti jemných prachových částic na povrchu tohoto materiálu. Díky těmto prachovým částečkám se často stává, že je narušen spoj mezi tmelem a podkladním materiálem. Tuto problémovost částečně odstraňuje nanesení primeru na podkladní materiál.

Tmely uvedené pro tento př́spěvek jsou vybrány na základě dostupnosti na trhu, doporučení výrobce tmelu pro vhodnost použit $\mathrm{k}$ tmelení tohoto problémového podkladu a také na základě svých vlastností, které jsou uvedeny $\mathrm{v}$ tab. 1. Je vybrán jeden zástupce neutrálních silikonů a jeden zástupce polyuretanových tmelů.

Na základě doporučení výrobce tmelu jsou k těmto tmelům vybrány primery, které mají za úkol zlepšit přilnavost samotného tmelu k podkladnímu materiálu.

\begin{tabular}{|l|c|c|}
\hline Vlastnosti & Tmel A & Tmel B \\
\hline Hustota $\left[\mathbf{g} / \mathbf{c m}^{\mathbf{3}}\right]$ & 1,0 & 1,23 \\
\hline Pevnost v tahu [N/mm2] & 1,5 & 1,4 \\
\hline Konzistence & $\begin{array}{c}\text { Tixotropní } \\
\text { pasta }\end{array}$ & $\begin{array}{c}\text { Tixotropní } \\
\text { pasta }\end{array}$ \\
\hline Elastický modul pružnosti [N/mm2] & 0,35 & 0,7 \\
\hline Tvrdost dle Shore A & 20 & 40 \\
\hline
\end{tabular}

Tab. 1 Vlastnosti tmelů $[5,6]$

\section{METODIKA}

Zkušební postup a metodika v tomto článku vychází z platné evropské normy ČSN EN ISO 9047 Stavební konstrukce - Těsnící hmoty - Stanovení přilnavosti a soudržnosti tmelů při proměnlivé teplotě.

Ve zmíněné normě je definována skladba a rozměry zkušebního tělesa. Zkušební těleso se skládá ze dvou podkladních destiček, dvou rozpěrek a tmelu. Rozměry zkušebního tělesa definované normou lze změnit, ale pouze za předpokladu, že zůstane zachován rozměr tmelu a plocha přilnavosti. 
Pro tento článek jsou použita zkušební tělesa, která se skládají ze dvou podkladních sklocementových destiček o rozměru $50 \times 30 \mathrm{~mm}$ a tloušt'ce $12,5 \mathrm{~mm}$. Dále pak ze dvou rozpěrek o půdorysných rozměrech rozměru $12 \times 9 \mathrm{~mm}$ a výšce $50 \mathrm{~mm}$. Rozpěrky jsou voleny dřevěné, a to $\mathrm{z}$ důvodu lepšího př́stupu vzduchu ke tmelené spáře a tím lepšímu vyzrávání tmelu. Dohromady tvoří podkladní sklocementové destičky a dřevěné rozpěrky ohraničení půdorysného prostoru o rozměrech $12 \times 12 \mathrm{~mm}$ pro aplikaci tmele. Společně s tmelem tvoří zkušební těleso pro následné testování.

Již zmíněná technická norma přesně specifikuje podmínku, za které jsou zkušební tělesa vyráběna. Touto podmínkou je konstantní teplota $(23 \pm 2){ }^{\circ} \mathrm{C}$. Dále to jsou podmínky stanovené výrobcem tmelu, a to naprríklad použití primeru atd. Norma také stanovuje opatření, která je při výrobě zkušebních těles nutno dodržet a jsou to: vyloučit tvorbu vzduchových bublin, přitlačit těsnící tmel ke stykovým plochám podkladních destiček a povrch tmelu uhladit do roviny podkladních destiček a rozpěrek.

Norma dále stanoví minimální počet zkušebních těles potřebných pro provedení zkoušky. Tento počet je určen počtem tří zkušebních těles, avšak autor tohoto příspěvku volí zkušebních těles hned pět, a to z důvodu většího množství výsledků, a tudíž i lepšímu zhodnocení výsledků zkoušky.

Zkušební tělesa se před samotným testováním musejí podrobit tzv. kondiciování, což znamená vystavení zkušebních těles předepsanému postupu stanoveného normou. Zkušební tělesa se nejprve po dobu 28 dnů uloží při teplotě $(23 \pm 2){ }^{\circ} \mathrm{C}$ a relativní vlhkosti $(50 \pm 5) \%$, aby došlo ke správnému vyzrání tmelu. Poté se zkušební tělesa podrobí třikrát následujícím cyklům uložení:

- $\quad 3$ dny v sušárně při teplotě $(70 \pm 2)^{\circ} \mathrm{C}$

- 1 den v destilované vodě o teplotě $(23 \pm 2)^{\circ} \mathrm{C}$

- $\quad 2$ dny v sušárně při teplotě $(70 \pm 2){ }^{\circ} \mathrm{C}$

- 1 den v destilované vodě o teplotě $(23 \pm 2)^{\circ} \mathrm{C}$

Po tomto kondiciování se zkušební tělesa před zkoušením další dobu mezi 24 hodin a 6 dny při teplotě $(70 \pm 2){ }^{\circ} \mathrm{C}$ a relativní vlhkosti $(50 \pm 5) \%$.

Pro samotnou realizaci zkoušení zkušebních těles jsou využita zkušební zařízení vyrobené již v předchozím výzkumu tmelů.

Princip této zkoušky spočívá v cyklickém natahování a stlačování zkušebních těles za proměnlivé teploty. Zkušební tělesa se protahují a stlačují rychlostí $(5,5 \pm 0,7) \mathrm{mm} /$ minutu o amplitudě $\pm 25 \%$. Síŕka tmelu při protažení při amplitudě $\pm 25 \%$ je $15,0 \mathrm{~mm}$ a šířka tmelu př̌i stlačení při téže amplitudě činí 9,0 $\mathrm{mm}$. Zkušební tělesa se podrobí následujícím cyklům střídavého protahování a stlačování při amplitudě $\pm 25 \%$

\section{První týden}

1. den: Zkušební tělesa se umístí do chladící komory při teplotě $(-20 \pm 2){ }^{\circ} \mathrm{C}$. Po třech hodinách se zkušební tělesa protáhnou ve zkušebním zařízení při amplitudě $\pm 25 \%$. Toto protažení se udržuje po dobu 21 hodin prí teplotě $(-20 \pm 2)^{\circ} \mathrm{C}$.

2. den: Uvolní se protažení. Zkušební tělesa se umístí do sušárny při teplotě $(70 \pm 2)^{\circ} \mathrm{C}$. Po třech hodinách se zkušební tělesa stlačí ve zkušebním zařízení při amplitudě $\pm 25 \%$. Stlačení se udržuje po dobu 21 hodin prri teplotě $(70 \pm 2)^{\circ} \mathrm{C}$.

3. den: Uvolní se stlačení a opakuje se postup 1. dne.

4. den: Uvolní se protažení a opakuje se postup 2. dne. 
5.-7. den: Uvolní se stlačení a zkušební tělesa se uloží při teplotě $(23 \pm 2){ }^{\circ} \mathrm{C}$ a relativní vlhkosti $(50 \pm 5)$ $\%$ bez použití mechanické síly.

\section{Druhý týden}

Během druhého týdne se opakuje postup prvního týdne.

Po ukončení zkoušek se zkušební tělesa prohlédnou, zda nedošlo k poruchám přilnavosti nebo soudržnosti tmelu. Pomocí posuvného měřítka s přesností čtení $0,5 \mathrm{~mm}$ se změří délka případné poruchy přilnavosti nebo soudržnosti. [4]

\section{VÝSLEDKY}

V tab. 2 jsou zaznamenány výsledky zkoušky, které jsou provedeny pro neutrální silikon a polyuretanový tmel.

Hodnocení zkoušky probíhalo tak, že všechna zkušební tělesa byla nejprve vizuálně zkontrolována, zda došlo či nedošlo k porušení celistvosti, výsledek této kontroly je v tabulce výsledků zaznamenán slovy Vydržel/Nevydržel. V př́padě porušení celistvosti zkušebního tělesa je poznamenán druh porušení a je změřena délka porušení posuvným měřítkem.

Vzorky, u nichž nedošlo k žádnému porušení celistvosti jsou v tabulce popsány slovem Žádné, a naopak $\mathrm{u}$ vzorků u nichž došlo k porušení celistvosti jsou v tabulce popsány druhem porušení a jeho délkou v milimetrech.

\begin{tabular}{|c|c|c|c|c|c|}
\hline \multicolumn{3}{|c|}{$\begin{array}{c}\text { Neutrální silikon } \\
\text { Tmel A }\end{array}$} & \multicolumn{3}{c|}{$\begin{array}{c}\text { Polyuretanový tmel } \\
\text { Tmel B }\end{array}$} \\
\hline č. & Spoj & $\begin{array}{c}\text { Porušení } \\
\text { Délka }\end{array}$ & č. & Spoj & $\begin{array}{c}\text { Porušení } \\
\text { Délka }\end{array}$ \\
\hline 1 & Vydržel & Žádné & 1 & Nevydržel & $\begin{array}{c}\text { Jednostranné odtržení } \\
48 \mathrm{~mm}\end{array}$ \\
\hline 2 & Nevydržel & $\begin{array}{c}\text { Jednostranné odtržení } \\
27 \text { mm }\end{array}$ & 2 & Nevydržel & $\begin{array}{c}\text { Jednostranné odtržení } \\
39 \text { mm }\end{array}$ \\
\hline 3 & Nevydržel & $\begin{array}{c}\text { Jednostranné odtržení } \\
30 \text { mm }\end{array}$ & 3 & Nevydržel & $\begin{array}{c}\text { Jednostranné odtržení } \\
50 \text { mm }\end{array}$ \\
\hline 4 & Vydržel & Žádné & 4 & Nevydržel & $\begin{array}{c}\text { Jednostranné odtržení } \\
49 \text { mm }\end{array}$ \\
\hline 5 & Nevydržel & $\begin{array}{c}\text { Jednostranné odtržení } \\
25 \text { mm }\end{array}$ & 5 & Nevydržel & $\begin{array}{c}\text { Jednostranné odtržení } \\
49 \text { mm }\end{array}$ \\
\hline
\end{tabular}

Tab. 2 Zkouška dle ČSN EN ISO 9047 


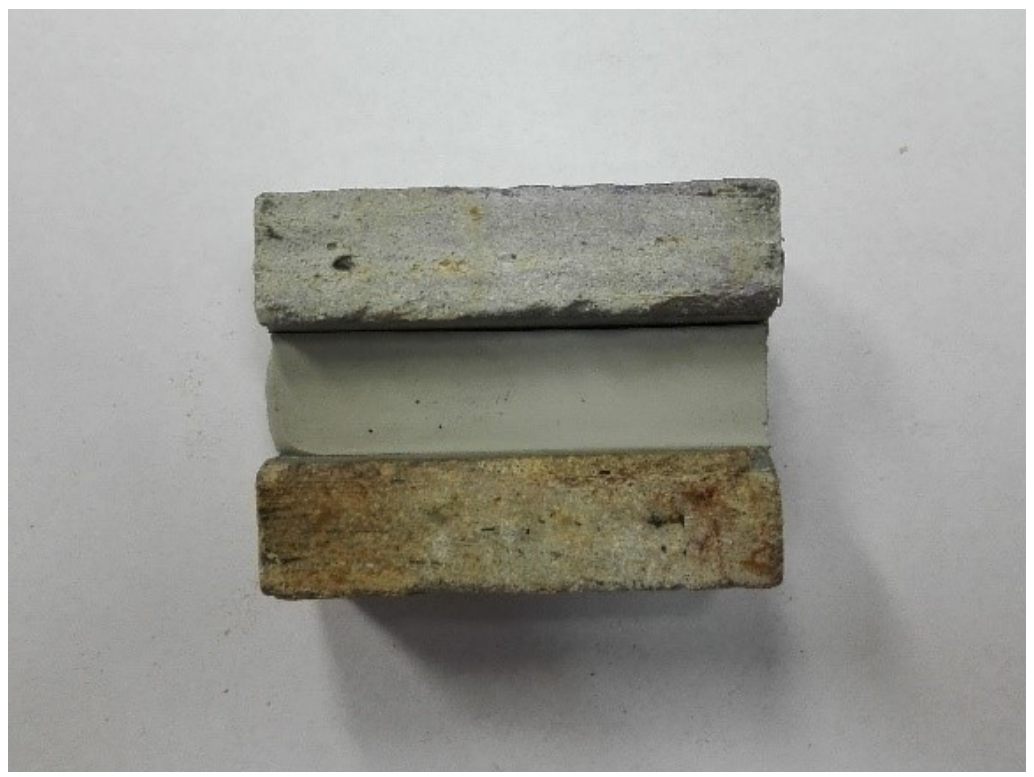

Obr. 1 Tmel B, vzorek č.3 Jednostranné odtržení délky 50 mm

\section{ANALÝZA VÝSLEDKŮ}

Při cyklickém natahování a stlačování při změně teploty došlo pouze k jednomu typu porušení zkušebních těles, a to $\mathrm{k}$ jednostrannému odtržení tmelu od podkladního materiálu. Při pohledu na tabulku výsledků je patrné, že tmel B si vedl podstatně hưře, než tmel A. U tmelu B došlo k porušení celistvosti u všech testovaných těles a délka porušení nabývá vysokých hodnot. Oproti tomu tmel A si vedl lépe. K porušení celistvosti došlo pouze u tří zkušebních těles s tím, že délky porušení jsou kratší než u tmelu B. I přesto, že u tmelu A nedošlo u dvou zkušebních vzorků k žádnému porušení tento tmel nelze hodnotit jako vyhovující.

\section{ZÁVĚR}

I přes to, že jsou tmely vybrány na základě doporučení výrobce pro tmelení vybraného podkladu, je z výsledkové tabulky patrné, že jak neutrální silikon, tak polyuretanový tmel nevyhoví při vystavení vlivu změn teplot, a to $\mathrm{v}$ př́ípadě, kdy jsou použity výrobcem požadované primery, které mají za úkol zlepšit přilnavost a soudržnost tmelu a podkladního materiálu. Vybrané tmely nejsou vhodné pro tmelení podkladního materiálu na bázi cementu a nelze je tedy $\mathrm{k}$ tomuto účelu doporučit.

\section{Poděkování}

Př́spěvek vznikl za podpory Standardního specifického výzkumu Vysokého učení technického v Brně s registračním číslem FAST-S-20-6338 a Juniorského specifického výzkumu s registračním číslem FAST-J-20-6359. 


\section{Použitá literatura}

[1] PETRIE, Edward M. Handbook of adhesives and sealants. New York: McGraw-Hill company, 2009. ISBN 0-07-049888-1.

[2] KLOSOWSKI, Jerome a Andreas T. WOLF. Sealants in construction. 2nd edition. Boca Raton: Taylorand Francis Group, 2016. ISBN 978-1-4200-1785-4.

[3] LAL MITTAL, Kashmiri a Antonio PIZZI. Handbook of sealant technology. Boca Raton: Taylor and Francis Group, 2009. ISBN 978-0-8493-9162-0.

[4] ČSN EN ISO 9047 Stavební konstrukce - Těsnící hmoty - Stanovení přilnavosti a soudržnosti tmelů při proměnlivé teplotě. Praha: Český normalizační institut, 2003.

[5] Denbraven [online]. Tech-vision, 2021 [cit. 2021-01-27]. Dostupné z: https://www.denbraven.cz/

[6] Sika [online]. 2018 [cit. 2021-01-27]. Dostupné z: https://cze.sika.com/ 